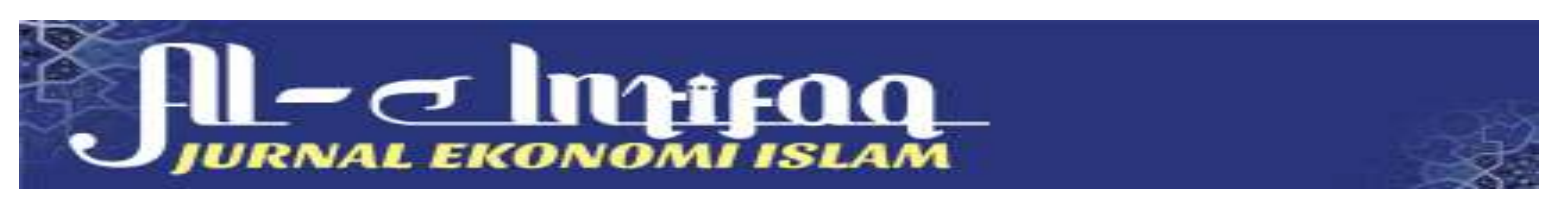

\title{
Analisis Pengaruh Investasi, Indeks Pembangunan Manusia Dan Tenaga Kerja Terhadap Pertumbuhan Ekonomi (Studi Pada Sumatera Barat Tahun 2010-2019)
}

\author{
Syofria Meidona ${ }^{1}$, Virell Prastama², Elsa Fitri Amran ${ }^{3}$ \\ Sekolah Tinggi Ilmu Ekonomi Sumatera Barat ${ }^{1}$, IAIN Batusangkar ${ }^{2}$ \\ syofriameidona@gmail.com¹, virellprastama12@gmailcom², \\ elsafitriamran@iainbatusangkar.ac.id ${ }^{3}$
}

\begin{abstract}
This study aims to determine how to analyze the effect of investment, human development index, and labor on the economic growth of West Sumatra in the 20102019 period. The data used in this study is secondary data, namely panel data consisting of time series data over a period of ten years, namely 2010-2019. The method used for sampling this research using saturated sampling. This study uses the SPSS program version 23. Based on the hypothesis testing carried out using multiple linear regression analysis with the results $Y=20.139+0.001 X_{1}-0.208 X_{2}-0.017 X_{3}$ at a significance level of 0.05 on the three variables, with an investment value of count 0.774 $<$ ttable1,943, sig value $0.468>0.05$ indicates a positive direction, $H D I t_{\text {count }}-3.360>t_{\text {table }}$ 1.943 , sig value $0.015<0.05$ indicates negative direction, and Labor $t_{\text {count }} 0.774<t_{\text {table }}$ 1.943, Sig value $0.58>0.05$ indicates Negative direction, the results of this study prove that partially the human development index affects economic growth, while the investment and labor variables do not affect economic growth. The results of simultaneous research on investment, human development index, and labor have a significant effect on economic growth with $t_{\text {count }} 5,137>t_{\text {table }} 4,76$, sig value $0.043<0.05$.
\end{abstract}

Keywords: Investment, Human Development Index, Labor, Economic growth

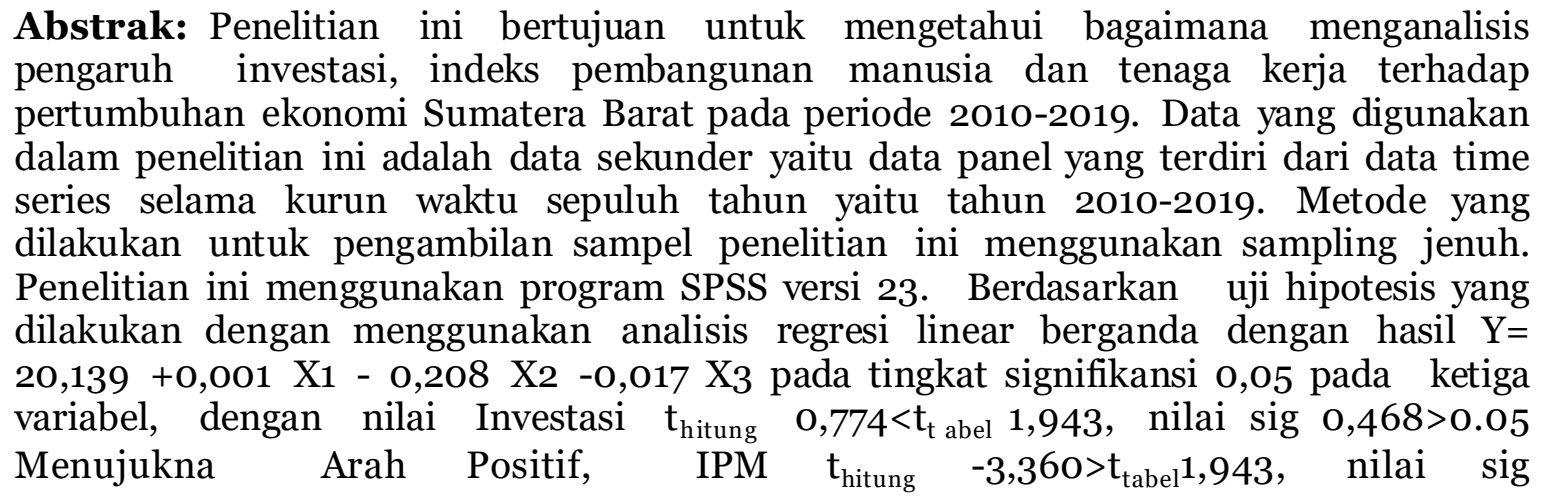


0,015< 0,05 Menujukkan arah Negatif, dan Tenaga Kerja t hit un g 0,774 < ttabel 1,943, Nilai Sig 0,58 > 0.05 menunjukan arah Negatif, maka hasil penelitian ini membuktikan bahwa secara parsial indeks pembangunan manusia berpengaruh terhadap pertumbuhan ekonomi, sedangkan untuk variabel investasi dan tenaga kerja tidak berpengaruh terhadap pertumbuhan ekonomi. Hasil penelitiaan secara simultan investasi, indeks pembangunan manusia, dan tenaga kerja berpengaruh secara signifikan terhadap pertumbuhan ekonomi dengan nilai thitun $\mathrm{g}$ 5,137>ttabel4,76, Nilai sig 0,043<0,05

Kata Kunci: Investasi, Indeks Pembangunan Manusia, Tenaga Kerja, Pertumbuhan Ekonomi

\section{PENDAHULUAN}

Pertumbuhan ekonomi merupakan kenaikan jangka panjang dalam kemampuan suatu Negara untuk menyediakan semakin banyak barang- barang ekonomi kepada penduduknya (Kuznet, 2011). Penelitian ini berfokus pada pertumbuhan ekonomi di Provinsi Sumatera Barat, karena pertumbuhan ekonomi di sumatera barat perlu di tingkatkan, agar dapat meningkatkan perkembangan dan pertumbuhan perekonomian secara fluktuatif.

\section{Gambar 1 \\ Laju Pertumbuhan Ekonomi Sumatera Barat}

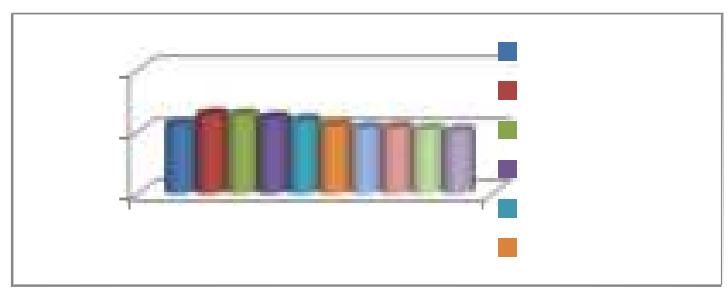

Berdasarkan Gambar 1. 1 diatas terlihat bahwa pertumbuhan ekonomi Sumatera Barat berfluktuasi. Namun dari tahun 2012 hingga tahun 2019 pertumbuhan ekonomi Sumatera Barat selalu mengalami penurunan. Rata-rata pertumbuhan ekonomi Sumatera Barat sebesar 5,65\%. Pertumbuhan ekonomi tertinggi terjadi pada tahun 2011 dengan pertumbuhan ekonomi mencapai $6,34 \%$ sedangkan yang terendah terjadi pada tahun 2019 dengan pertumbuhan ekonomi hanya sebesar 5,05\%. Hal ini tentunya tidak bagus bagi perekonomian Sumatera Barat.

Dalam meningkatkan pertumbuhan perekonomian tersebut tidak terlepas dari variabel-variabel makro ekonomi seperti investasi, tenaga kerja dan indeks pembangunan manusia.

Dalam upaya memenuhi tujuan tersebut pemerintah diharapkan mampu mengalokasikan dana investasi secara maksimal demi meningkatkan pertumbuhan ekonomi daerah. Menurut Rauf (2010), pengalokasian investasi perlu diarahkan kepada lapangan usaha yang membangkitkan perekonomian daerah, memperkecil 
kesenjangan distribusi pendapatan dan pengurangan kemiskinan. Untuk itu alokasi investasi perlu diprioritaskan kepada pertumbuhan ekonomi. Dengan meningkatnya investasi, maka akan tercipta kesempatan kerja dan sumber pendapatan masyarakat dan akhirnya berdampak bagi pengurangan kemiskinan dan lapangan usaha ekonomi lain yang memiliki keterkaitan dengan pertumbuhan ekonomi.

Faktor lain yang menjadi penetu pertumbuhan ekonomi adalah Indeks Pembangunan Manusia. Menurut United Nation Development Program (1990) untuk mengukur kesuksesan dan untuk mengukur kesuksesan dan kesejahteraan suatu deerah salah satu indikatornya yaitu Indeks Pembangunan Manusia, IPM merupakan tolak ukur kesejahteraan suatu daerah atau Negara dilihat berdasarkan empat dimeni yaitu terdiri dari angka harapan hidup pada waktu lahir, angka melek hidup, rata-rata lama sekolah dan kempuan daya beli. Pembangunan manusia yang tinggi berdampak pada peningkatan jumlah penduduk sehingga dapat meningkatkan tingkat konsumsi. Hal ini akan mempermudah untuk menggalakkan pertumbuhan ekonomi

Faktor yang mempengaruhi pertumbuhan ekonomi adalah kondisi tenaga kerja di wilayah tersebut. Todaro (2010) menyebutkan bahwa pertumbuhan penduduk dan pertumbuhan tenaga kerja secara tradisional dianggap sebagai salah satu faktor positif yang memacu pertumbuhan ekonomi. Jumlah tenaga kerja yang besar berarti akanmenambah tingkat produksi, sedangkan pertumbuhan penduduk yang lebih besar berarti ukuran domestiknya lebih besar.

Selanjutnya Menurut Lewis (1954) dalam Todaro (2004) tenaga kerja yang homogen dan tidak terampil dianggap bisa bergerak dan beralih dari sektor tradisional ke sektor modern secara lancar dan dalam jumlah terbatas. Penawaran tenaga kerja mengandung elastisitas yang tinggi. Meningkatnya permintaan atas tenaga kerja (dari sektor tradisional) bersumber pada ekspansi kegiatan sektor modern.

\section{KAJIAN TEORI}

\section{Pertumbuhan Ekonomi}

Pertumbuhan konomi merupakan syarat penting untuk mengentaskan masyarakat dari kemiskinan, walaupun pertumbuhan ekonomi tidak bisa berdiri sendiri untuk mengentaskan kemiskinan, tetap pertumbuhan ekonomi menjadi faktor utama untuk mengentaskan kemiskinan. Pada Todaro 2010 menurut Kuznets, pertumbuhan ekonomi adalah kenaikan kapasitas dalam jangka panjang dari negara yang bersangkutan untuk menyediakan berbagai barang ekonomi kepada penduduknya. Kenaikan kapasitas itu sendiri ditentukan atau dimungkinkan oleh adanya kemajuan atau penyesuaian- penyesuaian teknologi, institusional (kelembangaan) dan ideologis terhadap berbagai tuntutan keadaan yang ada.

\section{Investasi}

Teori ekonomi mengartikan atau mendefinisikan investasi sebagai pengeluaranpengeluaran untuk membeli barang-barang modal dan peralatan- peralatan produksi dengan tujuan untuk mengganti dan terutama menambah barang-barang modal dalam 
perekonomian yang akan digunakan untuk memproduksi barang dan jasa di masa yang akan datang. Peranan penting kegiatan investasi dalam perekonomian adalah salah satu komponen dari pengeluaran agregat, sehingga kenaikan investasi akan meningkatkan permintaan agregat dan pendapatan nasional.

Dana investasi dalam penelitiaan ini adalah PMA (Penanaman Modal Asing), jenis investasi yang sumber modalnya berasal dari luar negeri, sedangkan PMDN (Penanaman Modal Dalam Negeri) ialah jenis investasi yang sumber modalnya berasal dari dalam negeri.

\section{Indeks Pembangunan Manusia}

Konsep atau definisi pembangunan manusia tersebut pada dasarnya mencakup dimensi pembangunan yang sangat luas. Dalam konsep pembangunan manusia, pembangunan seharusnya dianalisis serta dapat dipahami dari sudut manusianya bukan hanya dari pertumbuhan ekonominya. Indeks Pembangunan Manusia digunakan untuk mengukur sberapa besar dampak yang dtimbulkan dari upaya peningkatan kemampuan modal dasar manusia. Indeks Pembangunan Manusia (IPM) merupakan alat ukur yang dapat menunjukkan persentase pencapaian dalam pembangunan manusia dengan memperhatikan tiga faktor yaitu kelangsungan hidup, pengetahuan dan daya beli.

\section{Tenaga Kerja}

Pengertian tentang tenaga kerja yang dikemukakan oleh Simanjuntak (2012) memiliki pengertian yang lebih luas dari pekerja/buruh. Pengertian tenaga kerja disini mencakup tenaga kerja/buruh yang sedang terkait dalam suatu hubungan kerja dan tenaga kerja yang belum bekerja. Sedangkan pengertian dari pekerja/buruh adalah setiap orang yang bekerja dengan menerima upah atau imbalan dalam bentuk lain. Dengan kata lain, pekerja atau buruh adalah tenaga kerja yang sedang dalam ikatan hubungan kerja. tenaga kerja adalah setiap penduduk yang mampu menghasilkan barang dan jasa untuk memenuhi kebutuhan hidupnya, dengan batas usia minimal angkatan kerja yaitu 15 tahun.

\section{Kerangka Pemikiran dan Hipotesis}

\section{Kerangka Pemikiran}

\section{Gambar 2}

Kerangka Pemikiran

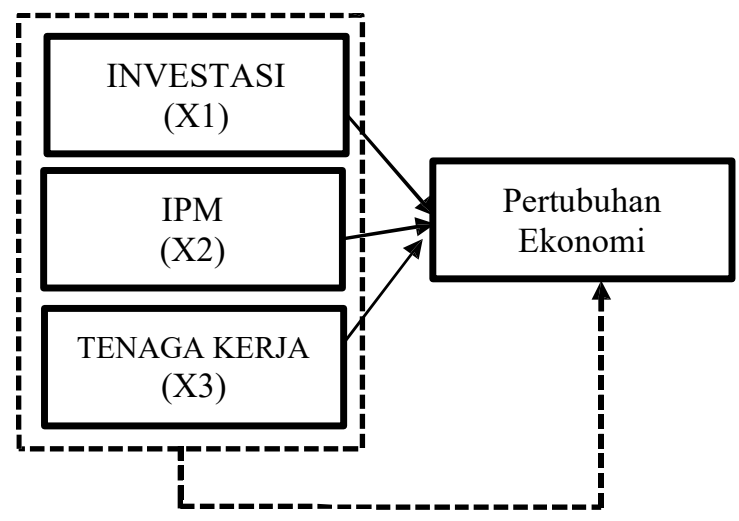




\section{Keterangan $=$ Parsial - . . . - s simultan}

Berdasarkan uraian diatas, maka hipotesis pertama dalam penelitian ini adalah:

$\mathrm{H}_{1}$ : Investasi berpengaruh terhadap pertumbuhan ekonomi.

$\mathrm{H}_{2}$ : Indeks Pembangunan Manusia berpengaruh terhadap pertumbuhan ekonomi

$\mathrm{H}_{3}$ : Tenaga Kerja berpengaruh terhadap pertumbuhan ekonomi

$\mathrm{H}_{4}$ : Investasi, Indeks Pembangunan Manusia, dan Tenaga Kerja berpengaruh terhadap Pertumbuhan Ekonom.

\section{METODE PENELITIAN}

\section{Jenis Penelitian}

Jenis penelitian ini merupakan penelitian deskriptif kuantitati. Penulis melakukan penelitian deskriptif, dimana menurut Novandri (2016) penelitian deskriptif digunakan untuk memperoleh deskripsi yang lengkap tentang subjek penelitian, dan pada penilitian ini penulis berupaya untuk memperoleh deskripsi yang lengkap dan akurat darifaktor- faktor yang mempengaruhi pertumbuhan ekonomi Sumatera Barat tahun 2010-2019. Penelitian kuantitatif menurut Sugiyono (2012) yaitu suatu metode penelitian yang dilandaskan pada filsafat positivisme yang digunakan untuk meneliti populasi dan sampel tertentu. Objek penelitian dalam penelitian ini dilakukan pada Sumatera Barat tahun 2010 sampai tahun 2019. Objek yang diteliti adalah mengenai Investasi, Indeks Pembangunan Manusia, Tenaga Kerja, dan Pertumbuhan Ekonomi.

\section{HASIL PENELITIAN DAN PEMBAHASAN}

\section{Statistik Deskriptif}

Berdasarkan pengolahan statistic deskriptif penelitian, diperoleh angka yang dijelaskan dalam table 1.

Tabel 1

Analisis Deskriptif

\begin{tabular}{|l|c|c|c|c|c|}
\hline \multicolumn{1}{|c|}{ Variabel } & $\mathrm{N}$ & $\mathrm{Min}$ & $\mathrm{Max}$ & Mean & $\begin{array}{c}\text { Std. } \\
\text { Deviation }\end{array}$ \\
\hline Invetasi & 10 & $-41,65$ & 302,30 & 42,1220 & 104,97205 \\
\hline IPM & 10 & 67,25 & 72,39 & 69,7760 & 1,72948 \\
\hline Tenaga Kerja & 10 & $-1,60$ & 8,71 & 2,1510 & 3,48454 \\
\hline $\begin{array}{l}\text { Pertumbuhan } \\
\text { Ekonoomi }\end{array}$ & 10 & 5,05 & 6,34 & 5,6520 & 0,47532 \\
\hline
\end{tabular}




\begin{tabular}{|l|l|l|l|l|l|}
\hline $\begin{array}{l}\text { Valid N } \\
\text { (listwise) }\end{array}$ & 10 & & & & \\
\hline
\end{tabular}

Sumber: Hasil olahan SPSS 23

\section{Hasil Uji Normalitas Data}

Salah satu cara mendeteksi apakah residual berdistribusi normal atau tidak, dapat dilihat dengan menggunakan uji One Sample Kolmogorov- Smirnov berikut ini:

\section{Tabel 2}

Hasil Uji Normalitas Data One-Sample Kolmogorov-Smirnov

\begin{tabular}{|c|c|c|c|}
\hline & & $\begin{array}{c}\text { Unstandar } \\
\text { dized } \\
\text { Residual }\end{array}$ & \\
\hline $\mathrm{N}$ & & & 10 \\
\hline Normal & Mean & 0.00000000 & \\
\hline Parameters & \begin{tabular}{|l} 
Std. Deviation \\
\end{tabular} & 0.25161106 & \\
\hline Most & Absolute & & 0.171 \\
\hline Extreme & \begin{tabular}{|l} 
Positive \\
\end{tabular} & & 0.153 \\
\hline Differences & \begin{tabular}{|l} 
Negative \\
\end{tabular} & -0.171 & \\
\hline Test Statisti & & & 0.171 \\
\hline Asymp. Sig. & iled) & & 0.200 \\
\hline
\end{tabular}

\section{Sumber: Hasil olahan SPSS 23}

Berdasarkan Tabel 2 diatas terlihat bahwa nilai Asymp.Sig. (2-tailed) sebesar 0,200 > 0,05. Data dinyatakan normal jika lebih besar dari 0,05, sehingga dapat disimpulkan secara uji Kolmogorov-Smimov bahwa data dari penelitian berdistribusi normal

\section{Hasil Uji Multikolinearitas}

Nilai cut off yang umum dipakai untuk menunjukkan adanya multikolinieritas adalah nilai tolerance $\geq 0,10$ atau sama dengan melihat angka Variance Inflation Factor (VIF). Jika $0,1<\mathrm{VIF}<10$, maka tidak terjadi multikolinearitas.

Tabel 3

Hasil Uji Multikolinearitas

Coefficients $^{a}$

\begin{tabular}{|c|c|c|c|}
\hline \multirow{2}{*}{\multicolumn{2}{|c|}{ Model }} & \multicolumn{2}{|c|}{ Collinearity Statistics } \\
\hline & & Tolerance & VIF \\
\hline \multirow[t]{4}{*}{1} & (Constant) & & \\
\hline & Investasi & 0.939 & 1.065 \\
\hline & IPM & 0.967 & 1.034 \\
\hline & Tenaga Kerja & 0.853 & 1.172 \\
\hline
\end{tabular}

a. Dependent Variable: Pertumbuhan Ekonomi 


\section{Sumber: Hasil olahan SPSS 23}

Hasil uji multikolinearitas pada tabel 3 terlihat pada kolom Collinearty statistic. Nilai Variance Inflation Factor (VIF). Variabel independenInvestasi nilai VIF sebesar 1,076 dimana nilai VIF lebih kecil dari 10 dan nilai tolerance pada investasi sebesar 0,929dimana nilai tolerance lebih besar dari 0,10. Maka dapat disimpulkan bahwa variabel independen investasi dalam penelitian ini menunjukkan hasil tidak terjadi multikolinearitas. Variabelindependen selanjutnya indeks pembangunan manusia nilai VIF sebesar 1,082dimana nilai VIF tersebut lebih kecil dari 10 dan nilai tolerance pada indeks pembangunan manusia sebesar 0,924dimana nilai tolerance lebih besar dari 0,10. Maka dapat disimpulkan bahwa variabel indeks pembangunan manusia dalam penelitiaan ini menunjukkan hasil tidak terjadi multikolinearitas. Dan variabel independen berikutnya adalah variabel tenaga kerja nilai VIF sebesar 1,050 dimana nilai VIF tersebut lebih kecil dari 10 dan nilai tolerance pada tenaga kerja sebesar 0,953dimana nilai tolerance lebih besar dari 0. 10. Sehingga dapat disimpullkan bahwa variable tenaga kerja dalam penelitiaan ini menunjukkan hasil tidak terjadi multikolinearitas

\section{Hasil Uji Heteroskedastisitas}

Heteroskedastisitas pada model regresi dapat diketahui dengan melihat grafik plot antara nilai prediksi variabel terikat (dependen) yaitu ZPRED dengan residualnya SRESID. Jika terdapat pola tertentu seperti titik yang membentuk pola tertantu yang teratur (bergelombang, melebar kemudian menyempit atau membentuk bentuk lain), maka mengidentifikasikan telah terjadi heteroskedastisitas. Jika tidak ada pola yang jelas serta titik menyebar diatas dan dibawah angka 0 pada sumbu $Y$, maka tidak terjadi heteroskedastisitas Ghozali (2016:134). Berikut ini hasil uji heteroskedastisitas dengan scatterplot.

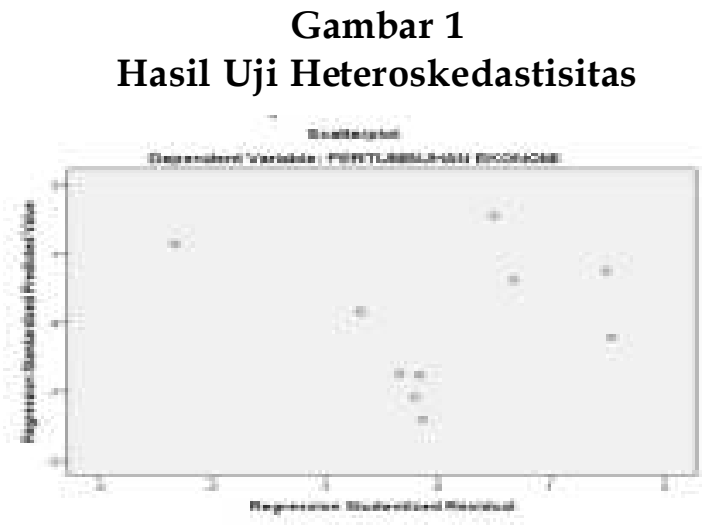

Sumber: Hasil olahan SPSS 23 
Dari gambar diatas terlihat bahwa titik-titik menyebar secara acak serta tersebar baik diatas maupun dibawah 0 pada sumbu Y. Hal ini dapat disimpulkan bahwa tidak terjadi heteroskedastisitas pada model regresi ini, sehingga model regresi layak untuk digunakan dalam melakukan pengujian.

\section{Hasil Uji Autokorelasi}

Dalam penelitian ini digunakan Durbin-Watson test untuk menguji autokorelasi.

\section{Tabel 4}

Hasil Uji Autokorelasi

Model Summary ${ }^{b}$

\begin{tabular}{|l|c|c|}
\hline Model & $\begin{array}{c}\text { Std. Error of the } \\
\text { Estimate }\end{array}$ & $\begin{array}{l}\text { Durbin- } \\
\text { Watson }\end{array}$ \\
\hline 1 & 0.30816 & 1.274 \\
\hline
\end{tabular}

Sumber: Hasil olahan SPSS 23

Dari hasil hitungan SPSS 23 diatas, maka diperoleh nilai Durbin-Watson (DW) adalah sebesar 1,2 Berdasarkan uraian tersebut maka: $\mathrm{dl}<\mathrm{d}<\mathrm{du}=0,5253<1,274<2,0163$. Dengan demikian perhitungan tersebut tidak dapat di simpulkan karena berada pada daerah yang tidak meyakinkan (inconclusive).

\section{Hasil Analisis Regresi Linear Berganda}

Hasil regresi linear berganda yang dapat dilihat pada tabel 5 sebagai berikut 
Tabel 5

Hasil Regresi Linear Berganda

Coefficients $^{\mathrm{a}}$

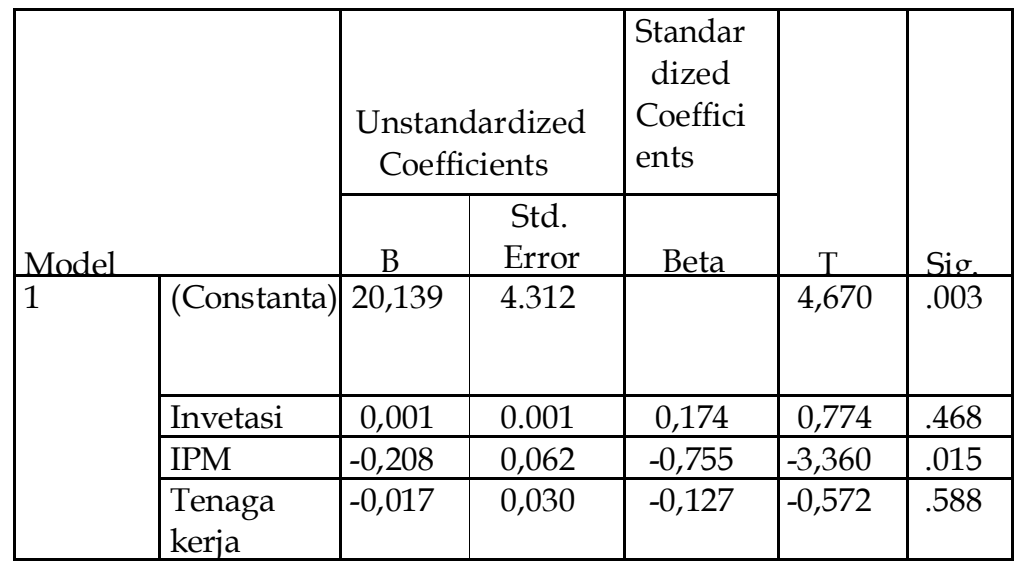

Sumber: Hasil Olahan SPSS 23

Hasil Uji Koefisien Determinasi (Uji $\left.R^{2}\right)$

Tabel 6

Hasil Uji Koefisien Determinasi (Uji $\left.\mathbf{R}^{2}\right)$

Model Summary ${ }^{b}$

\begin{tabular}{|l|c|c|l|l|}
\hline Model & $\mathrm{R}$ & $\begin{array}{c}\mathrm{R} \\
\text { Square }\end{array}$ & $\begin{array}{l}\text { Adjusted } \\
\text { R Square }\end{array}$ & $\begin{array}{c}\text { Std. Error } \\
\text { of the } \\
\text { Estimate }\end{array}$ \\
\hline 1 & $0.848^{\mathrm{a}}$ & 0.720 & 0.580 & 0.30816 \\
\hline
\end{tabular}

a. Predictors: (Constant), Tenaga kerja, Invetasi, IPM

b. Dependent Variable : Pertumbuhan Ekonomi

Sumber: Hasil olahan SPSS 23

Dari tabel 6 menunjukkan bahwa nilai Adjusted $R$ Square sebesar 0,580 atau 58\%maka dapat dikatan bahwa variabel independen (investasi, indeks pembangunan manusia dan tenaga kerja) berpengaruh terhadap variabel dependen pertumbuhan ekonomi karena nilai adjusted R square mendekati 1.

\section{Hasil Pengujian Hipotesis}

Pengujian hipotesis dalam penelitian ini menggunakan uji F dan uji t. Adapun uji hipotesisnya adalah sebagai berikut: 
Tabel 7

Hasil Uji Statistik F ANOVA ${ }^{a}$

\begin{tabular}{|l|l|l|l|l|l|l|}
\hline \multicolumn{2}{|l|}{} & $\begin{array}{l}\text { Sum of } \\
\text { Squar es }\end{array}$ & & Mean Squa re & & \\
\hline \multirow{2}{*}{$\begin{array}{l}\text { Regressi } \\
\text { on }\end{array}$} & 1,464 & 3 & 0.488 & $\begin{array}{c}5,13 \\
7\end{array}$ & $\begin{array}{c}0.04 \\
3\end{array}$ \\
\cline { 2 - 7 } & Residual & 0,570 & 6 & 0.095 & & \\
\cline { 2 - 7 } & Total & 2,033 & 9 & & & \\
\hline
\end{tabular}

a. Dependent Variable: Pertumbuhan Ekonomi

Berdasarkan tabel 7 diatas, dengan tingkat signifikansi sebesar 0,043 yang nilainya di bawah 0,05. Hal ini Hal ini menunujukkan bahwa Ho Ditolak dan Ha Diterima. Dengan demikian Hipotesis Keempat $(\mathrm{H} 4)$ diterima, jadi semua variabel independen yaitu investasi, indeks pembangunan manusia, dan tenaga kerja berpengaruh signifikan secara simultan (bersama-sama) terhadap Pertumbuhan Ekonomi.

\section{Uji Signifikan Parameter Individual}

(Uji Statistik $t)$

Hasil pengujian hipotesis dengan uji $\mathrm{t}$ adalah sebagai berikut:

Tabel 8

Hasil Uji Statistik $\mathbf{t}$

Coefficients $^{\mathrm{a}}$

\begin{tabular}{|c|c|c|c|c|c|c|}
\hline & & $\begin{array}{l}\text { Unsta } \\
\text { Coeffi }\end{array}$ & & $\begin{array}{l}\text { Standardiz } \\
\text { ed Coefficien ts }\end{array}$ & & \\
\hline & & B & $\begin{array}{l}\text { Std. } \\
\text { Error }\end{array}$ & Beta & & \\
\hline 1 & $\begin{array}{l}\text { (Consta } \\
\text { nt) }\end{array}$ & $\begin{array}{l}20,13 \\
9\end{array}$ & 4,312 & & $\begin{array}{l}4,67 \\
0\end{array}$ & $\begin{array}{l}0.00 \\
3 \\
\end{array}$ \\
\hline & Invetasi & 0,001 & 0,001 & 0,174 & $\begin{array}{l}0,77 \\
4 \\
\end{array}$ & $\begin{array}{l}0.46 \\
8\end{array}$ \\
\hline & IPM & 0,208 & 0,062 & $-0,755$ & \begin{tabular}{|l} 
\\
3,36 \\
0
\end{tabular} & $\begin{array}{l}0.01 \\
5\end{array}$ \\
\hline 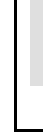 & $\begin{array}{l}\text { Tenaga } \\
\text { Kerja }\end{array}$ & 0,017 & 0,030 & $-0,127$ & $\begin{array}{l}0,57 \\
2\end{array}$ & $\begin{array}{l}0,58 \\
8\end{array}$ \\
\hline
\end{tabular}

a. Dependent Variable: Pertumbuhan Ekkonomi

\section{Sumber: Hasil olahan SPSS 23.}




\section{PEMBAHASAN}

Pengaruh Investasi terhadap Pertumbuhan Ekonomi

Berdasarkan pada table 8 diatas uji regresi parsial (Uji t) menunjukkan bahwa nilai signifikansi variabel investasi (X1) sebesar 0,468 yang lebih besar dari 0,05. Hal ini menunjukkan bahwa variabel investasi tidak memiliki pengaruh signifikan terhadap Pertumbuhan Ekonomi. Hal terseb ut diperkuat dengan nilai $t_{\text {hit ung yang lebih }}$ kecil dari nilai $t_{\text {tabel yaitu }} t_{\text {hit ung }} 0,774<t_{t}$ abel 1,943 dan menu njukkan arah positif. Dengan demikian Hipotesis pertama $\left(\mathrm{H}_{1}\right)$ ditolak, jadi variable investasi tidak berpengaruh signifikan terhadap perumbuhan ekonomi.

\section{Pengaruh Indeks Pembangunan Manusia terhadap Pertumbuhan Ekonomi}

Berdasarkan pada table 8 diatas uji regresi parsial (Uji t) menunjukkan bahwa nilai signifikansi variabel IPM (X2) sebesar 0,015 yang lebih kecil dari 0,05. Hal ini menunjukkan bahwa variabel IPM memiliki pengaruh signifikan terhadap Pertumbuhan Ekonomi. Hal tersebut diperkuat dengan nilai $t_{\text {hitung }}$ yang lebih besar dari nilai $t_{\text {tabel }}$ yaitu $t_{\text {hitung }}-3,360>t_{\text {tabel }} 1,943$ dan menunjukkan arah negat if. Dengan demikian Hipotesis kedua $\left(\mathrm{H}_{2}\right)$ diterima, jadi variabel Indek Pembangunan Manusia berpengaruh signifikan terhadap Pertumbuhan Ekonomi.

\section{Pengaruh Tenaga Kerja terhadap Pertumbuhan Ekonomi}

Berdasarkan pada tabel 8 diatas uji regresi parsial (Uji t) menunjukkan bahwa nilai signifikansi variable tenaga kerja (X3) sebesar 0,588 yang lebih besar dari 0,05. Hal ini menunjukkan bahwa variabel tenaga kerja tidak memiliki pengaruh signifikan terhadap Pertumbuhan Ekonomi.

Pengaruh Invetasi, Indeks Pemabangunan Manusia dan Tenaga Kerja terhadap Pertumbuhan Ekonomi

Berdasarkan pada tabel 7 diatas uji regresi secara simultan (Uji f) menunjukkan bahwa nilai signifikansi sebesar 0,043 yang nilainya di bawah 0,05 . Hal ini menunujukkan bahwa Ho Ditolak dan Ha Diterima. Dengan demikian Hipotesis Keempat (H4) diterima, jadi semua variabel independen yaitu Investasi, Indeks Pembangunan Manusia, dan Tenaga Kerja berpengaruh signifikan secara simultan (bersama-sama) terhadap Pertumbuhan Ekonomi. 


\section{KESIMPULAN}

Berdasarkan penelitian dan pengumpulan data yang dilakukan, disimpulkan bahwa varibel Indek Pembangunan Manusia (IPM) berpengaruh terhadap pertumbuhan ekonomi, sedangkan variable Investasi, dan Tenaga Kerja tidak berpengaruh terhadap pertumbuhan ekonomi provinsi sumatera barat.

Berdasarkan hasil olahan data menggunakan uji simultan, dinyatakan bahwa variebel Investasi, IPM, dan Tenaga Kerja mempengaruhi pertumbuhan ekonomi provinsi Sumatera Barat

\section{DAFTAR PUSTAKA}

Anonim,Penelitian Kuantitatif dan Deskriptif. Universitas Islam Negeri Maulana Malik Ibrahim di akses dari http://etheses.uin-malang.ac. id/1560/7/11520066_Bab_3.pdf

Anonim. (2010). Teori Tahap-Tahap Pertumbuhan ekonomi. https://protuslanx. wordpress. com/2010/10/23/teori-tahap-tahap- pertumbuhan-walt-whitmanrostow/

Anwar, Syaiful (2018). Analisi Teori-teori pertumbuhan ekonomi sebuah studi literatur. Universitas Negeri Adalas http://scholar.unand.ac. id/41270/5/Skripsi\%20Lengkap. pdf

Dewi, Nyoman Lilya Santika (2014), Pengaruh Komponen Indeks Pembangunan Manusia Terhadap Pertumbuhan Ekonomi Provinsi Bali. jurnal: Fakultas Ekonomi dan Bisnis Universitas Udayana.

Hadi, Kurnia Ilham (2014), Analisis Faktor-Faktor yang memperngaruhi Pertumbuhan Ekonomi di Provinsi Sumatera Barat. Andalas University. Di akses dari http://repo. unand.ac.id/1124/

Laila Sunna (2016). Teori Pertumbuhan Ekonomi dan Pengertiannya. https://portal-ilmu. com/teori-teori- pertumbuhan-ekonomi/

Novandri, Reza (2019) Analysis of a City Readiness in Indonesia in Implementing Integrated Information Systems toward Smart City Actualization. Conference: Proceedings of the International Conference on Innovation in Research (ICIIR 2018) - Section: Economics and Management Science. DOI: 10. 2991/iciir-18.

2019. 7

Radjab, Enny dan Andi Jam'an 2017, Metodologi Penelitian Bisnis, Universitas Muhammadiyah Makasar, diakses dari http://repository.poliupg.ac. id/325/1/Buku\%20MetPen\%20Bis nis\%20Enny. pdf

Sayifullah, Emmalian. (2018), Pengaruh Tenaga Kerja sektor pertanian dan pengeluaran pemerintahan sektor pertanian terhadap produk domestik bruto sekor pertanian di indonesia. Jurnal ekonomi-qu, vol 8, No. 1. 
Sirusa, 2019. "defenisi Indeks Pembangunan Manusia (ipm)", https://sirusa.bps. go.id/sirusa/index. php/indikator/46

Susanto, Aris Budi dan lucky rachmawati, 2012. Pengaruh Indeks Pembangunan Manusia (Ipm) Dan Inflasi Terhadap Pertumbuhan Ekonomi Di Kabupaten Lamongan. Falkutas Ekonomi UNESA

Yudha, Okta ryan Pranata, 2013. Pengaruh Pertumbuhan Ekonomi, upah minimum, tingkat pengagguran terbuka, dan inflasi terhadap kemiskinan di indonesia tahun 2009-2011. Universitas Negeri Semarang. 
